\title{
Glossa biblijna jako problem badawczy
}

Zarys treści: Glossa biblijna w ostatnich 30 latach stała się obiektem intensywnych badań w różnych ośrodkach na całym świecie. Mimo ogromu włożonej pracy opiera się nadal gruntownemu rozpoznaniu, ustaleniu chronologii powstawania, a drogi rozchodzenia się tego sztandarowego paryskiego produktu intelektualnego nadal nie są znane. Autor rekapituluje najważniejsze osiągnięcia dotychczasowych dociekań i uwypukla główne problemy stające na drodze dalszych badań.

\begin{abstract}
Biblical glossary has become in the thirty recent years a subject of intensive studies in various scientific centres throughout the world. But, despite hard work, it still remains unexplored, with unknown chronology of development, and ways of popularisation of this Parisian flagship intellectual product. The author recapitulates the most important achievements made thus far, and emphasises main problems of further studies.
\end{abstract}

Stowa kluczowe: Biblia rękopiśmienna, Glossa biblijna, biblistyka średniowieczna, transmisja tekstu, organizacja tekstu na stronie, historia nauki, historia szkolnictwa

Key words: manuscript Bible, Biblical gloss, medieval Biblical studies, textual transmission, page layout, history of learning, history of education

Jednym z najdonioślejszych wydarzeń $\mathrm{w}$ dziejach historii nauki, a na pewno $\mathrm{w}$ dziejach historii nauki średniowiecznej, jest pojawienie się zespołu zjawisk w zakresie kultury umysłowej określanych wspólnym mianem renesansu XII w. W historii Biblii zapisał się on dwoma niezwykle istotnymi wydarzeniami: na samym wstępie tego okresu pojawia się nowy rodzaj komentarza do Biblii, przepisywany wraz z tekstem samego Pisma Świętego, zwany glossą, na przełomie zaś XII i XIII w. wykształca się nowoczesna postać Biblii, jednotomowa Biblia paryska. Jeżeli w ogóle można by ująć w jednym zdaniu wagę tych zjawisk w historii nauki, trzeba by powiedzieć, że studia nad Biblią walnie się przyczyniły do przechowania przez czasy upadku nauki, w nowych zaś warunkach odrodzenia kultury miejskiej do upowszechnienia metodologii pracy naukowej, przysłużyły się więc w istotny sposób dalszemu rozwojowi cywilizacji europejskiej. W niniejszym artykule zostanie nakreślony ważki i niesłychanie skomplikowany problem badawczy, jakim jest Glossa biblijna. Zrekapitulowane zostaną pokrótce dotychczasowe osiągnięcia i przedstawione najważniejsze problemy stojące przed badaczami tego zjawiska. Najpierw jednak, jeszcze przed przejściem do właściwego przedmiotu niniejszego artykułu, należy się przez chwilę zatrzymać nad uściśleniem terminologii, bez dokonania czego szczegółowe omawianie Glossy biblijnej będzie groziło daleko idącymi nieporozumieniami.

Termin „glosa” wywodzi się od greckiego słowa $\gamma \lambda \tilde{\omega} \sigma \sigma \alpha$ oznaczającego język, tak w rozumieniu organu wymowy, jak i systemu komunikacyjnego ${ }^{1}$. W obydwu tych znaczeniach wyraz ten przeniesiony

\footnotetext{
${ }^{1}$ Stownik grecko-polski, t. 1, red. Z. Abramowiczówna, Warszawa 1958, s. 471.
} 
został na grunt łaciny już w starożytności². W średniowieczu zyskał jeszcze jedną konotację - specyficznej formy komentarza przepisywanego wraz z wyjaśnianym tekstem, najpierw szkolnego, w sztukach wyzwolonych (przede wszystkim gramatyce), później zaś biblijnego lub prawniczego. Upowszechnił się do tego stopnia, że zaczęly powstawać od niego wyrazy pochodne: glosatus ${ }^{3}$, glosatura ${ }^{4}$, glosule i Glossa ordinaria ${ }^{6}$. Z łaciny część tych pojęć przeszła do polszczyzny.

W języku polskim termin „glosa” (lub „glossa” w starszej literaturze) jest nieco kłopotliwy. Zacznijmy od ilości spółgłosek „s” w wyrazie. Stownik ortograficzny Wydawnictwa Naukowego PWN (Warszawa 2004) zaleca pisownię ,glosa”, a Słownik języka polskiego pod redakcją Witolda Doroszewskiego definiuje ów termin następująco: „dopisek, uwaga wpisana między wierszami tekstu lub na marginesie, będąca tłumaczeniem lub wyjaśnieniem zwrotu czy wyrazu niejasnego albo obcego" i zauważa metaforyczne użycie w znaczeniu wszelkiego rodzaju uwag do tekstu ${ }^{7}$. Znaczenia komentarza biblijnego lub prawniczego twórcy słownika nawet nie odnotowali, zapewne uznając za konotację zbyt wyspecjalizowaną.

O ile potoczna polszczyzna doskonale sobie radzi, pozostając w obrębie powyższych uregulowań, to fachowa terminologia historyczna już na to pozwolić sobie nie może. Zaczerpnięty z łaciny termin ma bowiem nieznane językowi codziennemu wspomniane wyżej znaczenie specyficznego komentarza, a ponadto wykształcił wiele znaczeń pochodnych, których rozróżnienie ułatwia poprawne rozumienie literatury fachowej. Dlatego też warto skorzystać z sytuacji, w której w dziejach języka polskiego funkcjonują dwie grafie tego słowa - „glosa” i ,glossa”. Pozwoli to na wprowadzenie dystynkcji, które $\mathrm{w}$ istotny sposób ułatwią poruszanie się po tym bardzo zagmatwanym polu.

W niniejszym artykule termin ,glosa”, zgodnie z normami słownikowymi, rozumiany będzie jako dopisek, uwaga marginalna lub interlinearna. Natomiast pojęcie ,glossa” będzie konsekwentnie stosowane $\mathrm{w}$ znaczeniu postaci przekazu tekstu biblijnego z dołączonym komentarzem, ujętym w ramy specyficznego układu lustra strony, łączącego tekst księgi biblijnej wyróżniony większym liternictwem i umieszczeniem $\mathrm{w}$ odrębnej kolumnie, $\mathrm{z}$ tekstem komentarza ujętym w zespół uwag (glos) zgromadzonych w osobnej kolumnie lub kolumnach obok tekstu komentowanego (glosy marginalne) i między wierszami tekstu komentowanego (glosy interlinearne). De facto glossa urasta więc do rangi gatunku literackiego, jakkolwiek autor niniejszych słów, czując się raczej mało kompetentny w zakresie genologii, nie podejmuje się kruszyć kopie w obronie tej być może zbyt pochopnej opinii. Poza tym definicja powyższa odnosi się tylko do glossy biblijnej, być może historycy prawa uznają za stosowne rozszerzyć ją także na glossy prawnicze.

Powyższe rozróżnienie nie wyczerpuje jednak problemów terminologicznych. Potrzebne jest jeszcze rozróżnienie glossy (komentarza) od Glossy, czyli zbioru gloss do wszystkich ksiąg biblijnych, których zestaw uległ w pewnym momencie zwyczajowemu ustaleniu, a na przełomie XIII i XIV w. przyjął miano Glossa ordinaria. W literaturze przedmiotu przyjęło się, w nieco anachroniczny sposób, używać tego pojęcia w odniesieniu do owego ustalonego tekstu także w stosunku do odpisów pochodzących z XIII, a nawet XII w. Ponieważ nie da się pominąć samego zjawiska, które zostało uznane za fakt historyczny, i trzeba je jakoś nazwać, termin Glossa wydaje się bardziej adekwatny niż anachroniczna Glossa ordinaria ${ }^{8}$. Tyle w kwestiach terminologicznych.

${ }^{2}$ Stownik łacińsko-polski, t. 2, red. M. Plezia, Warszawa 1962, s. 662.

3 Tzn. „opatrzony komentarzem typu glossa”, np. Job glosatus = Księga Hioba z glossą. Od ok. 1100 r. termin libri glosati odnosił się już wyłącznie do glosowanych ksiąg biblijnych; por. G. Lobrichon, Une nouveauté: les gloses de la Bible, w: Le Moyen Âge et la Bible, red. P. Riché, G. Lobrichon, Paris 1984, s. 97.

${ }^{4}$ Termin ten był używany wyłącznie dla określenia gloss do Psalmów i Listów św. Pawła autorstwa Anzelma z Laon (parva glosatura), Gilberta de la Porrée (media glosatura) i Piotra Lombarda (magna glosatura); por. niżej, s. 133-134.

5 Tzn. wszelkiego rodzaju uwagi dopisywane na marginesach Biblii, które nie należały do Glossy; por. L. Smith, The Glossa Ordinaria. The Making of a Medieval Bible Commentary, Leiden-Boston 2009, s. 3, przyp. 4.

${ }^{6}$ Por. niżej na tej stronie.

7 Stownik języka polskiego, t. 2, red. W. Doroszewski, Warszawa 1960, s. 1145.

${ }^{8}$ Co więcej, pozwala na odróżnienie od dzieła włoskiego jurysty Accursiusa (zm. 1260), twórcy Glossa ordinaria do prawa rzymskiego, przedstawiciela tzw. glosatorów, czyli badaczy należących do pierwszego okresu rozwoju nauk prawniczych. 
Dzieje Glossy aż roją się od błędnych mniemań, na czele których stoi mit o Walafridzie Strabonie. Jeszcze dziś w niektórych drukowanych opracowaniach i wypowiedziach wygłaszanych na konferencjach naukowych można spotkać jego echa. Według tej powszechnie niegdyś przyjmowanej legendy autorem Glossy, albo samej tylko zawartej w niej glossy marginalnej, był Walafrid Strabo. Choć błędne to przekonanie budziło wątpliwości już w XIX stuleciu, to ostatecznie upadło dopiero w XX w. pod ciężarem argumentów Beryl Smalley i Jeana de Blica9 .

Legenda ta ma rodowód renesansowy i związana jest z postacią opata Sponheim, sławnego Johannesa Trithemiusa; autorzy średniowieczni nie wymieniają Walafrida wśród twórców Glossy ${ }^{10}$. W swym najważniejszym dziele, De scriptoribus ecclesiasticis, Trithemius napisał: „Hic denique Strabus glosam quae ordinaria nunc dicitur super totam Bibliam ex dictis sanctorum patrum primus comportasse memoratur quam alii multis postmodum adiunctis sententiis patrum ampliarunt"11. Opinię tę niemal dosłownie powtórzył w wydanej rok później pracy Catalogus illustrium virorum ${ }^{12}$.

Komentując mistyfikację Trithemiusa, Karlfried Froehlich zwrócił uwagę na motywację patriotyczną. Opat Sponheim był członkiem założonej przez Konrada Celtisa Sodalitas Rhenana i podzielał jego romantyczne zapatrywania na przeszłość germańską. W swym pisarstwie chętnie przeciwstawiał się francuskim i włoskim opiniom o niższości kulturowej Niemców. Kiedy więc znalazł na pierwszej stronie glossy do Księgi Rodzaju nazwisko Walafrida Strabona - faktycznie źródła jednej z glos marginalnych - łatwo przyszło mu rozciągnięcie autorstwa karolińskiego uczonego na całość Glossy.

Jak się okazuje, mistyfikacja związana z Walafridem Strabonem nie była jedynym tego typu „osiągnięciem" w karierze pisarskiej Trithemiusa. Zasłynął on także wymyśleniem postaci Hunibalda Franka, rzekomego historiografa z czasów Chlodwiga, i Meginfrida z Fuldy, fikcyjnego kronikarza piszącego o początkach opactwa Hirsau ${ }^{13}$.

Opinia Trithemiusa, bezkrytycznie powtarzana przez innych pisarzy XVI-wiecznych, u schyłku stulecia weszła do przedmowy wydania drukowanego glosowanej Biblii (Paryż 1590) i odtąd królowała we wszystkich opracowaniach. W XIX w. trafiła nawet do Patrologii Jean-Paula Migne'a, który, zgodnie z krytycznym zmysłem swych czasów, wyczyścił Glossę z wszystkich późniejszych autorów oraz z uwag interlinearnych, czyniąc tym samym swe wydanie zupełnie bezużytecznym dla dzisiejszych historyków ${ }^{14}$.

Mit o Walafridzie Strabonie ma jedną konsekwencję, która, o ile autorowi tych słów wiadomo, nie została jeszcze nigdy właściwie naświetlona. Otóż za pojęciami glossa marginalna i glossa interlinearna nie stoi żadna rzeczywistość historyczna. Posługiwanie się nimi imputuje istnienie niezależnych zjawisk intelektualnych o charakterze summy biblijnych glos, pozycjonowanych obok tekstu Pisma

${ }^{9}$ Dzieje tej mistyfikacji zrekonstruował K. Froehlich, Walafrid Strabo and the Glossa Ordinaria. The Making of a Myth, „Studia Patristica”, 28, 1993, s. 192-196; K. Froehlich, M.T. Gibson, Introduction, w: M.T. Gibson, "The Glossed Bible”, Biblia latina cum glossa ordinaria. Facsimile reprint of the editio princeps: Adolph Rusch of Strassburg 1480/81, t. 1, Turnhout 1992, s. XXIII-XXIV. B. Smalley, w artykułach publikowanych od lat 30. ubiegłego stulecia, wskazywała na Anzelma z Laon i innych właściwych autorów. Zdecydowanie przeciw Walafridowi Strabonowi wypowiedział się J. de Blic; tenże, L'oeuvre exégétique de Walafrid Strabon, et la Glossa Ordinaria, „Recherches de théologie ancienne et médiévale”, 16, 1949, s. 5-28. B. Smalley swe poglądy podsumowała najpierw w pracy The Study of the Bible in the Middle Ages, Notre Dame 1978, s. 56-60, a następnie w haśle Glossa ordinaria, w: Theologische Realenzyklopädie, t. 13, red. G. Müller, Berlin 1984, s. 452-457.

10 Por. K. Froehlich, Walafrid Strabo, s. 192-196.

11 Bazylea: [Johannes Amerbach], 1494, f. 44r; ISTC it00452000, Incunabula Short Title Catalogue. The International Database of 15 th-Century European Printing, <http://data.cerl.org/istc/it00452000> [dostęp: 13.06.2017]; GW M47578, Gesamtkatalog der Wiegendrucke, <http:/www.gesamtkatalogderwiegendrucke.de/docs/M47578.htm> [dostęp: 13.06.2017].

12 Moguncja: Peter von Friedberg, 1495; ISTC it00433000, Incunabula Short Title Catalogue, <http://data.cerl.org/istc/ it00433000> [dostęp: 13.06.2017]; GW M47516, Gesamtkatalog, <http://www.gesamtkatalogderwiegendrucke.de/docs/ M47516.htm> [dostęp: 13.06.2017]: „Iste Strabus vir studiosissmus glosam, quam magistralem siue ordinariam vocant, super totam Bibliam primus comportavit ex dictis sanctorum patrum, quam alii postmodum adiunctis quibusdam ampliarunt".

${ }^{13}$ K. Froehlich, Walafrid Strabo, s. 194; A. Grafton, Worlds Made by Words. Scholarship and Community in the Modern West, Cambridge (MA) 2011, s. 70-71.

${ }^{14}$ K. Froehlich, Walafrid Strabo, s. 196. 
Świętego lub między jego wierszami. Twory takie samodzielnie nigdy nie zaistniały. Możemy mówić jedynie o glosach marginalnych i interlinearnych!

Do lat 80. ubiegłego stulecia badania nad Glossą prowadzili co prawda uczeni miary B. Smalley lub Henri de Lubaca, ale interesowała ich ona tylko marginalnie. Dopiero w latach 80. uwagę badaczy przykuła Glossa jako taka i wówczas rozpoczął się ruch, zainicjowany w krajach anglosaskich, który z czasem objął szersze kręgi. Od początku panowało przekonanie, że aby poprawnie rozpoznać Glossę, należy przygotować jej edycję krytyczną. Ponieważ edycja J.-P. Migne’a w Patrologia Latina była całkowicie nieprzydatna do badań, nawet jako punkt wyjścia, a rękopisów było zbyt wiele, by wyselekcjonować chociażby zestaw najstarszych, oczy zwrócono w kierunku wczesnych wydań drukowanych. Pierwodruk Biblii z Glossą, dokonany w 1480 r. przez Adolpha Ruscha w Strasburgu ${ }^{15}$, sprawiał wrażenie wiernego dużej liczbie odpisów rękopiśmiennych. W 1992 r. wydawnictwo Brepols dokonało więc reprintu tej edycji, do którego dołączono artykuły wprowadzające pióra Margaret T. Gibson i K. Froehlicha ${ }^{16}$. Zdawało się, że droga do szybkiego uporania się z problemami stawianymi przez bogactwo odpisów i kłopoty z precyzyjnym określeniem pytań badawczych została otwarta. Okazało się jednak, że to nieprawda. Od początku lat 90. nad różnymi aspektami poszczególnych ksiąg Glossy pracuje coraz szerszy krąg badaczy, systematycznie rejestrowane są rękopisy, do współpracy zaprzęgnięto nowoczesną technikę komputerową, a postęp wiedzy na temat Glossy jest nadal bardzo powolny ${ }^{17}$. Z pewnością wiemy już dzisiaj na jej temat znacznie więcej, ale naszą wiedzę być może najlepiej charakteryzuje stwierdzenie, że na obecnym etapie rozpoznania źródeł zdajemy sobie sprawę z faktu, że większość naszych uogólnień na temat Glossy jest oparta na analizie zaledwie niewielkiej części materiału rękopiśmiennego i będzie nadal modyfikowana. Słowem, to co się udało ustalić to fakty cząstkowe, dotyczące odpisów i grup odpisów poszczególnych ksiąg funkcjonujących w danym okresie na danym obszarze, a formułowane na tych podstawach uogólnienia są prowizoryczne.

Zacznijmy od opisania, czym jest glossa jako obiekt materialny, albowiem to właśnie specyficzna postać organizacji tekstu, albo raczej tekstów na stronie, uczyniła ją czymś wyjątkowym. Dla uproszczenia posłużmy się sytuacją modelową. Rękopis glossy jest bardzo charakterystyczny. Od każdego innego komentarza glossę odróżnia fakt, że kopista zamieszcza na każdej stronie dwa równolegle teksty, z których jeden stanowi wyjaśnienie drugiego. Teksty te w żadnym wypadku nie mogły zostać przez czytelnika pomylone - jeden z nich, tekst główny, czyli glosowany, był obdarzony autorytetem najwyższym, drugi zaś, czyli glosy, odnosił się do pierwszego jako komentarz. Teksty były wyodrębnione graficznie: stronę dzielono na trzy pionowe kolumny. Tekst główny zajmował kolumnę środkową i naniesiony był pismem dwu- lub trzykrotnie większym niż komentarze. Jego poszczególne wiersze wprowadzano z szeroką interlinią. Komentarz umieszczano w dwóch kolumnach okalających (glosy marginalne) oraz bardzo drobnym pismem między wierszami tekstu głównego (glosy interlinearne).

Tekst komentowany (księga biblijna) jest ciągły - zaczyna się na pierwszej stronie glossy i, dawkowany na każdej następnej w krótszych lub dłuższych fragmentach, dobiega końca na ostatniej. Komentarz w glossie nie jest utworem ciągłym. Składa się z szeregu niezależnych całostek, których objętość jest bardzo różna. Glosy interlinearne z reguły są bardzo zwięzłe. Często są to pojedyncze słowa (czasami nawet w postaci skróconej), niekiedy - równoważniki zdań lub pełne zdania, rzadko zdarza się, że liczą kilka zdań. Glosy marginalne nigdy nie przyjmują postaci pojedynczego słowa lub równoważnika zdania, najkrótsze liczą jedno pełne zdanie. Najczęściej są to swoiste artykuły, obejmujące od kilku po kilkaset wierszy, rozciągających się na kilka kolejnych kolumn glossy, czyli na kilka następujących po sobie stron.

Glosy naturalną koleją rzeczy powinny być graficznie powiązane $\mathrm{z}$ tekstem głównym, by było wiadomo, która uwaga odnosi się do którego słowa lub fragmentu tekstu biblijnego. W przypadku glos

\footnotetext{
15 [Strasburg: Adolf Rusch, 1480-1481]; ISTC ib00607000, Incunabula Short Title Catalogue, <http://data.cerl.org/istc/ ib00607000?lang=de\&format=csv\&orig=1\&style=full\&file=yes $>$ [dostęp: 13.06.2017]; GW 04282, Gesamtkatalog, <http:// gesamtkatalogderwiegendrucke.de/docs/GW04282.htm> [dostęp: 13.06.2017].

16 K. Froehlich, M.T. Gibson, Introduction, s. VII-XII.

${ }^{17}$ Spośród historyków polskich nieco uwagi glossie poświęcił: S. Wielgus, Badania nad Biblia w starożytności $i$ w średniowieczu, Lublin 1990, s. 86-87.
} 
interlinearnych wprowadzane są albo nad, albo pod słowem lub frazą, do której się odnoszą. Jeśli zaś chodzi o glosy marginalne, to ich początki są korelowane w kolumnie obok z fragmentem Biblii, do którego się odnoszą. Jeżeli jednak do danego fragmentu odnosi się kilka glos, korelacja osiągnięta jest przez zastosowanie lemmy, czyli słowa lub frazy z tekstu głównego, do którego dana uwaga się odnosi, umieszczonej w początku glosy.

W przypadku glos marginalnych, które ciągną się przez kilka stron, powstaje problem ułatwienia czytelnikowi odnajdywania ciągu dalszego z kolumny na kolumnę ${ }^{18}$. W tym celu stosowano system znaków graficznych - najczęściej kombinacji kropek i kresek - które, stawiane u dołu kończącej się kolumny i u góry rozpoczynającej się, zapewniały łatwą orientację.

W glosach marginalnych obok lemmy mogą się pojawić także dwa inne elementy identyfikacyjne: imię autora, z którego pism zaczerpnięto glosę (np. „Jer” = Hieronimus) i określenie sensu Pisma Świętego, do którego dana interpretacja należy (np. ,all” = allegorice). Niestety nie jest to reguła, przeważająca część glos pozbawiona jest części lub wszystkich z powyższych identyfikatorów, zrzucając na barki czytelnika odgadnięcie, do którego miejsca odnosi się dana uwaga, czyjego jest autorstwa i jaki jest jej charakter.

W dawnych opracowaniach spotykamy stwierdzenia utrzymujące, że glosy marginalne wyjaśniają problemy i zwroty, linearne zaś - słowa. Jednak faktycznie nie ma takiego rozróżnienia: i jedne, i drugie zawierają treści odnoszące się zarówno do słów, jak i pojęć.

Powyższy opis ma charakter modelowy. Rzeczywistość rękopiśmienna jest znacznie bardziej skomplikowana, ponieważ rozplanowanie graficzne glossy rozwijało się w kierunku powiększania objętości komentarza, a w związku z tym coraz skrupulatniejszego wykorzystywania miejsca na rozkładówce książkowej. Poza tym kopiowanie gloss odbywało się w różnych warunkach. Paryscy kopiści, którzy pracowali w systemie nakładczym, przestrzegali bardzo rygorystycznie zasad powielania gloss. Inaczej było jednak z kopistami pracującymi poza Paryżem. Ich odpisy powstawały nieraz mechanicznie, bez wkładania wysiłku w zrozumienie struktury tekstu. Powodowało to przenoszenie glos marginalnych na kolejne strony, ponieważ kopiście brakowało miejsca na właściwej. Czasami zamieniali glosy interlinearne na marginalne i odwrotnie. Jeżeli do tego wszystkiego dodamy specyficzny język Glossy, niezwykle oszczędny, zarówno w warstwie znaczeniowej, jak i gramatycznej, okazuje się, że lektura Glossy, podejmowana nawet przez badaczy biegłych w średniowiecznej biblistyce, okazuje się zadaniem niezwykle trudnym, a zrozumienie niektórych glos wręcz niemożliwym.

Glosowanie znane było już w starożytności, ale glossę jako typ komentarza notujemy dopiero od czasów średniowiecznych. Jej rozwój wiąże się ze środowiskiem szkolnym i nauczaniem sztuk wyzwolonych. Przed wiekiem XII glossy powstawały zazwyczaj jako twory jednorazowe, tylko komentarz Serviusa do Eneidy Wergiliusza przepisywany był wielokrotnie. Tworzono także glossy do Biblii, ale nigdy nie osiągnęły one takiego znaczenia i rozpowszechnienia jak w XII w. Od początków tego stulecia notujemy gwałtowne upowszechnienie gloss biblijnych i prawniczych, komentujących kodyfikację justyniańską i podstawowe zbiory prawa kanonicznego. Glossa Accursiusa do korpusu prawa rzymskiego znana była również pod nazwą Glossa ordinaria ${ }^{19}$.

Pod koniec XI w. Anzelm z Laon (zm. 1117), kanonik tamtejszej kapituły, który nauczał w przykatedralnej szkole sztuk wyzwolonych, awansował do rangi wykładowcy Pisma Świętego. Przygotowując się do wykonywania tych obowiązków, zapewne przeniósł na grunt nowej tematyki swych wykładów formę, z której korzystał wcześniej - glossę. Anzelm osiągnął uznanie jako mistrz, a jego sława sięgała Paryża - dowodzi tego jednoznacznie złośliwe świadectwo Piotra Abelarda ${ }^{20}$. Zapewne pod wpływem autorytetu Anzelma w jego otoczeniu zaczęły powstawać podobne glossy. Znamy imiona przynajmniej niektórych spośród wczesnych twórców gloss: Radulfa z Laon lub Gilberta z Auxerre zw. Universalis.

\footnotetext{
${ }^{18}$ Dłuższa glosa marginalna nigdy nie zajmowała jednocześnie dwóch kolumn okalających tekst główny na tej samej stronie, lecz była kontynuowana na jednej z kolumn następnej strony itd.

19 L. Smith, The Glossa Ordinaria, s. 5; zob. też T. Gross-Diaz, The Psalms Commentary of Gilbert of Poitiers. From Lectio Divina to the Lecture Room, Leiden-New York 1996, s. 38-39.

${ }^{20}$ Petrus Abaelardus, Historia calamitatum. Texte critique avec une introduction, red. J. Monfrin, Paris 1962, s. 68-70.
} 
Już przed połową wieku glosowanie stało się niesłychanie popularne, doprowadzając do gwałtownego powstawania gloss do różnych ksiąg Biblii. W drugiej połowie XII w. praktycznie całe Pismo Święte miało swe glossy, a ich tekst zaczął się ustalać - zaczęła funkcjonować Glossa, czyli to, co pod koniec XIII w. zaczęto nazywać Glossa ordinaria.

W tym momencie musimy wrócić znów do historii historiografii, by wyjaśnić, że dawniejsi badacze zbudowali elegancki schemat rozwoju Glossy, który przedstawia się w zasadniczych zarysach następująco: Anzelm napisał kilka gloss, ale najważniejsze z nich były glossy do Psalmów i Listów św. Pawła, które tradycyjnie określa się mianem parva glosatura. W latach 30. i 40. Gilbert de la Porrée przepracował je, nadając im dojrzalszą postać, którą za średniowiecznymi scholarami nazywamy media glosatura, w latach 50. zaś jego dzieło stało się podstawą prac paryskiego mistrza Piotra Lombarda, który stworzył dzieło nazywane magna glosatura.

Równocześnie powstawały glossy do pozostałych ksiąg Biblii i w ten sposób już ok. lat 20. XII w. ustalił się tekst Glossy, przez następne dziesięciolecia - do ok. 1220 r. - powielony w setkach praktycznie identycznych kopii. W trzeciej dekadzie XIII w. popularność Glossy nagle się załamała i odtąd jej egzemplarze przepisywane były tylko incydentalnie, a z nauczania Glossa została wyparta przez nowsze komentarze.

Przedstawiony wyżej schemat, ustalony przez historyków egzegezy biblijnej, linearny i logiczny, niestety nie wytrzymuje konfrontacji z rzeczywistością rękopiśmienną. Badacze, którzy zajęli się tym tematem w ostatnim trzydziestoleciu, wprowadzili do niego zasadnicze zmiany, a co więcej, dziś panuje opinia, że to, co obecnie sądzimy na temat powstania i rozwoju Glossy będzie w dalszym ciągu ulegało daleko idącym modyfikacjom.

Badania ostatnich lat nie tylko nie zakwestionowały, lecz wręcz utwierdziły przekonanie o pionierskiej roli Anzelma z Laon. To najprawdopodobniej on w swej praktyce dydaktycznej zaczął posługiwać się glossą, znaną mu z nauczania sztuk wyzwolonych. Zwrócono uwagę na fakt, że glossy w swej pierwotnej postaci są niczym innym jak konspektem, na podstawie którego nauczyciel mógł w koherentny sposób wykładać treść i interpretację danej księgi biblijnej, zachowując bez trudności ciągłość i zwartość wykładu.

Anzelmowi przypisywane jest autorstwo gloss do: Psalmów, Listów św. Pawła, Ewangelii św. Jana i - z pewnymi zastrzeżeniami - Ewangelii św. Łukasza. Wybór Psalmów i Listów św. Pawła jako pierwszych gloss wydaje się oczywisty. Psalmy stanowiły podstawę nie tylko liturgii, ale także nauczania w średniowieczu, Listy św. Pawła zaś odgrywały fundamentalną rolę w nauce Kościoła ${ }^{21}$.

W otoczeniu Anzelma działał Radulf z Laon, zapewne jego brat, chociaż nie można także wykluczyć interpretacji duchowej tego określenia. Jest to postać, o której praktycznie nic więcej nie wiemy. Radulf stworzył glossę do Ewangelii św. Mateusza, św. Jana i być może św. Łukasza.

Gilbert Universalis, kanonik z Auxerre, jest niemal równie nieuchwytny. Był jednocześnie teologiem i kanonistą, co niektórzy przyjmują za wyjaśnienie jego przydomka. Występuje w dokumentach laońskich w latach 1110-1120. Możliwe, że był także kanonikiem w Nevers. W 1128 r. został biskupem Londynu. Zmarł w 1134 r. Jemu najprawdopodobniej trzeba przypisać przygotowanie gloss do większości ksiąg biblijnych (Pięcioksięgu, Księgi Jozuego, Sędziów, Królewskich, proroków większych, proroków mniejszych, Lamentacji i Ewangelii św. Łukasza). Gilbert Universalis podpisywał swe glossy, co wskazuje na jego prawniczą formację $e^{22}$.

W kręgu laońskim działali także inni twórcy gloss. Jeden z nich nosił imię Alberyk (z Reims?). $Z$ jego imieniem łączone są glossy do Dziejów Apostolskich i ewentualnie Apokalipsy. Anonimowy autor lub autorzy z Laon napisali glossy do Księgi Hioba, Pieśni nad Pieśniami i Apokalipsy św. Jana ${ }^{23}$.

Atrybucja poszczególnych dzieł bardzo rzadko opiera się na podpisie złożonym przez autora. Najczęściej są to wiadomości podawane przez czytelników bądź kopistów, co może być obarczone sporym

${ }^{21}$ L. Smith, The Glossa Ordinaria, s. 32.

22 Tamże, s. 27-33.

${ }^{23}$ Tamże, s. 33. 
ryzykiem, ponieważ informacje te zapisywane bywały dużo później. W przypadku Anzelma z Laon, którego imię niegdyś łączono ze znacznie większą liczbą gloss niż dzisiaj, mamy także do czynienia z jego wielką sławą i autorytetem, co powodowało, że średniowieczni pisarze, nie znając faktycznego twórcy danej glossy, chętnie przypisywali pisma nieznanego autorstwa także jemu.

Najstarsze zachowane rękopisy gloss pochodzą z przełomu lat 30. i 40. XII w. Reprezentują one układ tekstu tzw. pierwszy albo prosty. Strona była dzielona na trzy kolumny o stałej szerokości, z których wewnętrzna zawierała tekst glosowany. Między wierszami tekstu głównego znajdowały się glosy interlinearne. Kolumny boczne zawierały glosy marginalne. Kolumny boczne były liniowane tylko w tych miejscach, gdzie faktycznie wpisana była glosa, podczas gdy kolumna środkowa była liniowana w sposób ciągły. Proporcje szerokości kolumn wynosiły najczęściej - 3:3:2. Kolumna wewnętrzna, bliska miejscu zszycia książki, na ogół była węższa. Jeżeli którakolwiek z kolumn była szersza od pozostałych, to była to kolumna tekstu komentowanego. Pismo tekstu zasadniczego było większe i z interlinią pozostawioną na glosę, pismo zaś glos - mniejsze. Na ogół trzy linijki glosy marginalnej przypadały na wiersz tekstu głównego, niekiedy - cztery. Czasem pismo glos „zachodziło” na kolumnę tekstu głównego. Indywidualne glosy często nie miały odsyłacza w postaci cytatu biblijnego (lemmy). Lemmy, jeżeli występowały, to na ogół nie były wyróżnione od reszty tekstu glossy. Początek każdej glosy zaznaczony był znakiem akapitu, które bywały ozdobne. Nie stosowano koloru w inicjałach, nie były używane odsyłacze graficzne łączące glosy z fragmentami tekstu, do których się odnosiły. Jeżeli odnajdujemy takowe $\mathrm{w}$ rękopisach, to są one późniejszymi dodatkami. W układzie pierwszym spotykamy też puste miejsca między glosami ${ }^{24}$.

O ile początki Glossy wiążą się ze środowiskiem laońskim, to jej dalszy rozwój wychodzi poza Laon, ale wielki sukces tej nowej formy komentarza biblijnego to sprawa paryska.

Badania przeprowadzone przez Theresę Gross-Diaz nad powstaniem media glosatura Gilberta de la Porrée radykalnie zaprzeczyły tradycyjnym poglądom na temat powstawania gloss do Psalmów i Listów św. Pawła. Amerykańska autorka wykazała, że dzieła Anzelma i Gilberta powstawały niejako równolegle i niezależnie od siebie. Gilbert był uczniem Anzelma i wówczas zapewne zapoznał się z pierwszą wersją parva glosatura, po czym opuścił Laon i samodzielnie już nauczając - najprawdopodobniej w Paryżu, a nie w Poitiers, a potem Chartres, jak chciała dawna historiografia - podjął pracę nad własnymi glossami. Gilbert glosował inaczej niż Anzelm, parafrazował raczej niż cytował swe źródła. Jeszcze przed śmiercią w 1117 r. Anzelm zapoznał się z glossą Gilberta - jest to poświadczone źródłowo - i albo sam wprowadził fragmenty z niej do swego dzieła, albo, co bardziej prawdopodobne, uczynili to ludzie z jego otoczenia już po jego śmierci ${ }^{25}$. Słowem, kierunek zapożyczeń faktycznie był odwrotny, niż wcześniej uważano. Rekonstrukcja sposobu powstania obydwu dzieł wyjaśnia także fakt, dlaczego nie znamy rękopisów parva glosatura sprzed 1130 r. - być może są, ale są one tak różne od znanej nam parva glosatura, że nie rozpoznajemy jej jako takiej.

Media glosatura różni się od parva także pod względem układu strony. Występuje w dwóch układach. Pierwszy z nich to klasyczna postać komentarza, w którym nie ma tekstu głównego - zastępują go lemmy; słowem nie jest to forma glossy. Druga to już forma glossy w układzie dwukolumnowym, w której kolumna tekstu biblijnego była węższa i ustawiona z prawej strony. Proporcje szerokości kolumn zmieniały się ze strony na stronę w zależności od potrzeby. Tekst biblijny pisany był większym pismem i w co drugiej linijce. Media glosatura nie znała glos interlinearnych. W tekście biblijnym występowały lemmy, które były podkreślone na czerwono lub czarno. Tekst biblijny był dzielony na fragmenty, by jego położenie odpowiadało miejscem komentarzowi do niego. Na marginesach wprowadzono odwołania do źródeł w postaci skróconych imion Ojców Kościoła lub tytułów ich dzieł. Gilbert de la Porrée konsekwentnie posługiwał się także numeracją psalmów, co w owych czasach było jeszcze wyjątkowe. Układ strony zastosowany w media glosatura nosi nazwę cum textu ${ }^{26}$.

\footnotetext{
${ }^{24}$ Co się tyczy szczegółowego omówienia układów Glossy zob. tamże, s. 91-139.

25 T. Gross-Diaz, The Psalms Commentary, s. 27-35.

${ }^{26}$ Tamże, s. 35-51.
} 
Powstanie magna glosatura nadal pozostaje słabo rozpoznane. Według późniejszych, aczkolwiek wiarygodnych przekazów, Piotr Lombard miał stworzyć swe glossy wyłącznie dla własnego użytku. Mimo to ok. 1160 r. zaczęły mnożyć się ich odpisy. Układ magna glosatura też był inny od pierwszego lub prostego. Każda strona dzieliła się w niej na dwie równej szerokości kolumny. Kolumny były liniowane równo, a w odpowiednich miejscach pojawiały się kapsułki z tekstem biblijnym, wpisanym większym liternictwem w co drugą linijkę. Układ ten nazywany jest intercessim. Układ zastosowany przez Piotra Lombarda posługuje się również odsyłaczami do źródeł, umiejscowionymi na marginesach, i również nie zna glos interlinearnych.

Badania nad rękopisami zadały też kłam dawnemu przekonaniu o linearnej sukcesji gloss, teorii głoszącej, że parva glosatura została wyparta przez media glosatura, która z kolei ustąpiła magna glosatura. Nie tylko okazało się, że glossy te funkcjonowały równolegle, ale także, że trwało to bardzo długo, faktycznie do końca zainteresowania Glossą. W wydaniu A. Ruscha znajduje się parva glosatura!

Tymczasem mnożące się glossy do pozostałych ksiąg biblijnych ok. 1160 r. zmieniły swe rozplanowanie graficzne: układ pierwszy albo prosty ustąpił drugiemu, który był dużo bardziej skomplikowany. Kolumna tekstu głównego w układzie drugim nie była stała. Jej szerokość zmieniała się nie tylko ze strony na stronę, lecz także na tej samej stronie, zdarzało się bowiem, że wchodziła na kolumnę prawą lub lewą i zajmowała miejsce między glosami. Liniowanie było jedne dla całej strony. Kolumny były bardzo różnej szerokości, w zależności od potrzeby. Kolumny glos potrafiły się rozdwajać, a także zachodzić na kolumnę tekstu głównego. Inicjałki były kolorowe - zazwyczaj na przemian niebieskie i czerwone. Graficzne znaki łączące, tak jak w układzie pierwszym, używane były dla powiązania tekstu kończącej się kolumny glosy z jej kontynuacją na następnej stronie.

Układ drugi był odpowiedzią na zmienioną sytuację. W połowie XII w. glossy przestały już być roboczą pomocą nauczyciela wykładającego Biblię. Zagęszczenie materiałów na stronie było tak duże, że szybka orientacja w przekazywanych treściach nie była już możliwa. Glossa stała się książką przeznaczoną do indywidualnej lektury i przemyśleń, a jej konstrukcja przywiodła angielskiemu badaczowi Davidowi A. Salomonowi skojarzenie $\mathrm{z}$ funkcją pełnioną przez hipertekst $\mathrm{w}$ dzisiejszych stronach internetowych ${ }^{27}$. Christopher de Hamel spróbował na podstawie cech formalnych lustra strony i opraw wyznaczyć chronologię odpisów Glossy, zasady pomagające w datowaniu odpisów, ale jego pomysły spotkały się z ostrożnym przyjęciem ${ }^{28}$.

Opisane wyżej układy pierwszy i drugi nie wyczerpują wszystkich typów spotykanych w rękopisach. Układy te powielano konsekwentnie najprawdopodobniej tylko w Paryżu, gdzie funkcjonował wspomniany już system nakładczy produkcji kopii Glossy, prowadzony przez wielkie klasztory. Oprócz egzemplarzy będących efektem tej produkcji spotykamy jeszcze inne, ewidentnie na paryskich wzorowane, ale niekonsekwentnie.

Z pewnością układ graficzny zastosowany w Glossie, dzięki swej prostocie i klarowności, istotnie przyczynił się do jej sukcesu. Jednak to nie układ treści był decydujący. W postaci Glossy użytkownik dostał do rąk Biblię wraz z przewodnikiem encyklopedycznym po jej treści, a na dodatek w klarownej i logicznej formie zewnętrznej. Glossa była w użytku prosta i wielce pouczająca. Jednocześnie dawała dostęp do tekstu Pisma Świętego i różnych poziomów jego interpretacji, według ówczesnych zapatrywań klasyfikowanych jako sens literalny i sensy przenośne. Podkreśla się, że wiek XII to czasy sensu literalnego, owego klucza do poprawnego rozumienia Biblii. Glossa jest więc jego kwintesencją biblistyki XII-wiecznej. Co więcej, czyniła to, opierając się na pismach uznanych autorytetów - jak wykazały badania, przede wszystkim Ojców Kościoła (Orygenes, Hieronim, Augustyn, Grzegorz Wielki), ale także teologów wieków późniejszych (Kasjodor, Izydor z Sewilli, Beda, Alkuin, Hraban Maur). Słowem, Glossa serwowała Słowo i Tradycję, a także narzędzia do ich poprawnego zrozumienia w jednym.

O ile dla czytelników Glossa była niezwykle atrakcyjna, z punktu widzenia kopisty musiała być poważnym wyzwaniem. Jej przepisywanie wymagało albo niewolniczego trzymania się wzorca pod

27 D.A. Salomon, An Introduction to the Glossa Ordinaria as Medieval Hypertext, Cardiff 2012.

${ }^{28}$ Ch. de Hamel, Glossed Books of the Bible and the Origins of the Paris Booktrade, Woodbridge 1984. 
względem zawartości poszczególnych linijek i stron, albo tworzenia własnego układu, który zachowywałby łączność między tekstem biblijnym a komentarzami. W tym drugim przypadku kopista musiał oczywiście rozumieć tekst przepisywany - mechaniczne przepisywanie nie wchodziło $\mathrm{w}$ grę. Zapewne stopień trudności związany z wykonaniem kopii powodował, że często nie pożyczano dostępnego na miejscu egzemplarza i nie wykonywano go lokalnymi siłami (z pewnością tańszymi) tylko przywożono nowy z Paryża. Okazuje się, że większość zachowanych XII-wiecznych kopii gloss przepisana została bardzo rygorystycznie i w ramach swoistego przemysłu nakładczego, który wykształcił się w Paryżu w wyniku wieloletniej działalności wielkich klasztorów. Jednak wobec stale rosnącego popytu nie radziły one sobie z samodzielną produkcją kopii. Postawiły więc na zorganizowaną pracę świeckich kopistów zewnętrznych. Ch. de Hamel postawił ciekawą tezę, że działalność ta walnie przyczyniła się do powstania świeckiej produkcji książki w tym mieście na przełomie XII i XIII w., kiedy świeccy kopiści się uniezależnili ${ }^{29}$. Był to kolejny element składający się na powstanie Uniwersytetu Paryskiego. Oczywiście nieprawdą jest, że w innych ośrodkach nie powstały warsztaty odpisujące glossy. Powstały $\mathrm{z}$ całą pewnością, ale żaden nie osiągnął znaczenia równego paryskiemu.

Około 1175 r. praktycznie wszystkie księgi biblijne były już dostępne w formie glossy. Jedynie Księga Barucha nigdy nie otrzymała glossy, a glossa do Ksiąg Machabejskich to po prostu komentarz Hrabana Maura, odpowiednio przeformatowany ${ }^{30}$. Stworzenie korpusu spowodowało zaistnienie w tych latach Glossy jako zjawiska intelektualnego, którego oddziaływanie było przemożne. Żaden inny tekst XII-wieczny nawet nie zbliża się ilością zachowanych odpisów do glossy, jest ich literalnie tysiące. Lesley Smith zestawiła znane średniowieczne odpisy gloss do Lamentacji, Ewangelii św. Jana i Pieśni nad Pieśniami, okazało się, że jest ich - odpowiednio - 100, 209 i 73. Łącznie daje to prawie 400 kopii, a mowa tu zaledwie o trzech glossach. Poza tym kwerenda ta jest z pewnością daleka od kompletności, z samych zbiorów polskich można dodać sporo uzupełnień. Zachowanych odpisów jest więc tysiące ${ }^{31}$.

Śledząc kolejne publikacje na temat Glossy, można wyraźnie dostrzec, jak przesuwa się w czasie moment, kiedy tekst Glossy był uznawany za „względnie” ustabilizowany. XIX- i XX-wieczni historycy egzegezy biblijnej uznali, że nastąpiło to ok. 1120 r. Piszący w latach 80. ubiegłego stulecia Ch. de Hamel, który dokonał szerokiej kwerendy źródłowej, pisze o okolicach 1130 r. ${ }^{32} \mathrm{~K}$. Froehlich przesuwa go już na połowę stulecia ${ }^{33}$. L. Smith twierdzi, że nastąpiło to wkrótce po $1200 \mathrm{r}^{34}$ Tymczasem własne doświadczenia badawcze autora niniejszego artykułu z rękopisem F22-94 Biblioteki im. Wróblewskich Litewskiej Akademii Nauk w Wilnie ukazują, że tekst Glossy do Księgi Koheleta przyrastał jeszcze w XIII w. ${ }^{35}$ Czyżby stabilizację tekstu Glossy trzeba było przenieść o kolejne dziesięciolecia? A może tekst Glossy, co wydaje się również prawdopodobne, nie ustabilizował się nigdy!

$\mathrm{Na}$ koniec trzeba koniecznie przypomnieć kwestię podniesioną już przeszło 50 lat temu przez B. Smalley, która zauważyła, że praktyka glosowania Biblii przez XII-wiecznych scholarów była znacznie szersza niż omawiany, najważniejszy nurt, który zlał się w zjawisko, które złożyło się na późniejszą Glossa ordinaria. W materiale rękopiśmiennym spotykamy masę gloss będących zjawiskiem jednorazowym i niezwykle trudno dających się łączyć z konkretnym obszarem, środowiskiem, nie wspominając już o osobach. B. Smalley zabytki te określiła jako glosses périmées. Zapewne ku jej zaskoczeniu termin ten przyjął się w literaturze i funkcjonuje do dziś. Niemniej zjawiskiem tych gloss ,przestarzałych” jak dotąd nikt się nie zają ${ }^{36}$.

\footnotetext{
29 Tamże, s. 85.

30 L. Smith, The Glossa Ordinaria, s. 26.

${ }^{31}$ Autor niniejszego artykułu rejestruje zachowane w zbiorach polskich średniowieczne rękopisy biblijne. Obecny stan rozpoznania nie pozwala jednak jeszcze na sformułowanie żadnych wniosków poza tym, że zachowało się ich dużo.

${ }^{32}$ Ch. de Hamel, Glossed Books, s. 4.

${ }^{33}$ K. Froehlich, An Extraordinary Achievement. The Glossa Ordinaria in Print, w: tenże, Biblical Interpretation from the Church Fathers to the Reformation, cz. 5, Variorum Collected Studies Series, 951, Farnham 2010, s. 16.

${ }^{34}$ L. Smith, The Glossa Ordinaria, s. 3.

${ }_{35}$ Autor przygotowuje artykuł na temat tego rękopisu.

${ }^{36}$ B. Smalley, Les commentaires bibliques de l'époque romane: glose ordinaire et gloses périmées, „Cahiers de civilisation médiévale", 4, 1961, s. 15-22.
} 
Niniejszy artykuł podejmuje tylko stronę bibliologiczną badań nad Glossą biblijną. Odrębnym zagadnieniem są relacje między tekstem Pisma Świętego przekazywanego przez Glossę a Biblią paryską. Hans Herman Glunz, pisząc w latach międzywojennych swą historię Wulgaty w Anglii do XIII w., stwierdził, że tekst Biblii paryskiej to tekst Biblii glosowanej z drugiej połowy XII w., czyli z czasów jej najbardziej burzliwego rozwoju ${ }^{37}$. Laura Light, amerykańska badaczka Biblii paryskiej, z pewnymi zastrzeżeniami podtrzymała tę opinięę

Niemniej problemów z Glossą jest więcej. By wymienić tylko kilka spośród ważniejszych: na odpowiedź czeka pytanie o rolę, jaką upowszechnienie glossy odegrało w rozwoju aparatu naukowego, potwierdzenia oczekuje śmiała teza Ch. de Hamela o roli glossy w powstaniu świeckiego rynku produkcji i obrotu książką w Paryżu na przełomie XII i XIII w., na badaczy czeka cały zespół zagadnień należących do historii teologii, itd. Na wszystkie te pytania odpowiedzieć będzie można w sposób zadowalający dopiero po rozpoznaniu całości zachowanego materiału źródłowego.

\section{Biblical glossary as a research problem}

Summary: The Biblical glossary is one of the most important phenomena in the history of medieval scholarship, it combines the text of the Scriptures with a commentary in a special graphic layout. It played an important part in the popularisation of the Biblical studies. The glossary appeared around the turn of the twelve century in northern France in the milieu of cathedral school at Laon, with the key figure of Master Anselm. Already before the mid-twelve century glosses to individual books of the Bible gained huge popularity, and had hundreds of copies. At a certain time - it is thought today that it was the early thirteenth century - the text of the Glossary got stabilised. And although in the thirteenth century its popularity began to fade, it was copied to the end of the medieval period, and then many times published in print.

Modern research into the glossary, although initiated in the nineteenth century, has in fact been developed in the 1980s. But ambitious source research and comparative analyses have shown that the Biblical glossary is a very difficult discipline. It was comparatively easy for researchers to have got through hagiographical legends that grew up around the glossary (for example the alleged authorship of Walafrid Strabon), but despite all the efforts only one book (Song of Songs) and some other fragments were published in a critical edition. In the course of ongoing studies more and more apparently "sure" points in our knowledge about the glossary are discredited, such as, for instance, the conviction that the glossary text had stabilised at one point of time. What hampers the research is mainly an enormous number of manuscript copies containing glosses, amounting to thousands of them. What is more, the production of those manuscripts was strictly standardised, making it difficult to establish not only their actual chronology, but also their place of origin. The research into the Biblical glossary is still a growing field of study.

Nota o Autorze: Jacek Soszyński, profesor nadzwyczajny w Instytucie Historii Nauki im. L. i A. Birkenmajerów PAN, kierownik projektu Manuscripta.pl. Zajmuje się historią książki i dziejami kronikarstwa uniwersalnego w średniowieczu.

Author: Jacek Soszyński, associate professor at the L. \& A. Birkenmajer Institute for the History Science, director of the Manuscripta.pl Project. He is interested in the history of the book and in medieval Latin universal chronicles.

Instytut Historii Nauki im. L. i A. Birkenmajerów PAN

ul. Nowy Świat 72, pok. A09

00-330 Warszawa

e-mail: pineus22@gmail.com

${ }^{37}$ H.H. Glunz, The Vulgate in England from Alcuin to Roger Bacon, Cambridge 1933.

${ }^{38}$ L. Light, Versions et révisions du texte biblique, w: Le Moyen Âge et la Bible, s. 81-83. 


\section{Bibliografia}

Blic J. de, L'oeuvre exégétique de Walafrid Strabon et la Glossa Ordinaria, „Recherches de théologie ancienne et médiévale", 16, 1949, s. 5-28

Froehlich K., An Extraordinary Achievement. The Glossa Ordinaria in Print, w: tenże, Biblical Interpretation from the Church Fathers to the Reformation, cz. 5, Variorum Collected Studies Series, 951, Farnham 2010, s. 15-21

Froehlich K., Makers and Takers. The Shaping of the Biblical Glossa Ordinaria, w: tenże, Biblical Interpretation from the Church Fathers to the Reformation, cz. 3, Variorum Collected Studies Series, 951, Farnham 2010, s. $1-19$

Froehlich K., Walafrid Strabo and the Glossa Ordinaria. The Making of a Myth, „Studia Patristica”, 28, 1993, s. $192-196$

Froehlich K., Gibson M.T., Introduction, w: M.T. Gibson, "The Glossed Bible”, Biblia latina cum glossa ordinaria. Facsimile reprint of the editio princeps: Adolph Rusch of Strassburg 1480/81, Turnhout 1992

Gibson M.T., The Place of the Glossa Ordinaria in Medieval Exegesis, w: Ad litteram. Authoritative Texts and their Medieval Readers, red. M.D. Jordan, K. Emery Jr., Notre Dame 1992, s. 5-27

Gibson M.T., The Twelfth-Century Glossed Bible, „Studia Patristica”, 23, 1989, s. 232-244

Glossa Ordinaria Pars 22: in Canticum Canticorum, red. M. Dove, Brepols 1997

Grafton A., Worlds Made by Words. Scholarship and Community in the Modern West, Cambridge (MA) 2011

Gross-Diaz T., The Psalms Commentary of Gilbert of Poitiers. From Lectio Divina to the Lecture Room, Leiden-New York 1996

Hamel Ch. de, Glossed Books of the Bible and the Origins of the Paris Booktrade, Woodbridge 1984

Light L., Versions et révisions du texte biblique, w: Le Moyen Age et la Bible, red. P. Riché, G. Lobrichon, Paris 1984, s. 55-93

Lobrichon G., Une nouveauté: les gloses de la Bible, w: Le Moyen Âge et la Bible, red. P. Riché, G. Lobrichon, Paris 1984 , s. $95-114$

Matter E.A., The Church Fathers and the Glossa Ordinaria, w: The Reception of the Church Fathers in the West from the Carolingians to the Maurists, red. I. Backus, Leiden-New York 1997, s. 83-111

Salomon D.A., An Introdyction to the Glossa Ordinaria as Medieval Hypertext, Cardiff 2012

Signer M.A., The Glossa Ordinaria and the Transmission of Mediaeval Anti-Judaism, w: A Distinct Voice. Medieval Studies in Honor of Leonard E. Boyle OP, red. J. Brown, W.P. Stoneman, Notre Dame 1977, s. 591-605

Simon M., La glose de l'Épitre aux Romains de Gilbert de la Porrée, „Revue d'histoire ecclésiastque”, 52, 1957, s. $95-114$

Smalley B., Gilbertus Universalis, Bishop of London (1128-34) and the Problem of the Glossa Ordinaria, „Recherches de théologie ancienne et médiévale”, 7, 1935, s. 235-262; 8, 1936, s. 24-60

Smalley B., La Glossa Ordinaria: quelques prédécesseurs d'Anselme de Laon, „Recherches de théologie ancienne et médiévale", 9, 1937

Smalley B., Glossa ordinaria, w: Theologische Realenzyklopädie, t. 13, red. G. Müller, 1984, s. 452-457

Smith L., The Glossa Ordinaria. The Making of a Medieval Bible Commentary, Leiden-Boston 2009

Smith L., The Glossed Bible, w: The New Cambridge History of the Bible, t. 2: From 600 to 1450, red. R. Marsden, E.A. Matter, Cambridge 2012, s. 363-379

Stirnemann P., Où ont été fabriqués les livres de la glose ordinaire dans la première moitié du XII siècle, w: Le $X I I^{e}$ siècle. Méditations et renouveau en France dans la première moitié du XII siècle, red. F. Gasspari, Cahiers du Léopard d'Or, t. 3, Paris 1994, s. 257-301

Wielgus S., Badania nad Biblia w starożytności i w średniowieczu, Lublin 1990

Projekt Glossae.net - http://glossae.net/en/content/glossaenet 